\title{
PELATIHAN PENGEMBANGAN INSTRUMEN PENILAIAN TEKNIK NON TES BAGI GURU MAN 4 KAMPAR
}

\author{
Sri Ulfa Insani ${ }^{1}$, Astuti $^{2}$, Zulfah $^{3}$ \\ ${ }^{1,2,3)}$ Program Studi Pendidikan Matematika, Fakultas Ilmu Pendidikan, Universitas Pahlawan Tuanku \\ Tambusai \\ e-mail: sriulfainsanishelly@gmail.com
}

\begin{abstract}
Abstrak
Pengabdian kepada masyarakat ini dilaksanakan di MAN 4 Kampar. Adapun materi yang diberikan adalah pengembangan instrumen penilaian teknik non tes bagi guru yang ada di MAN 4 Kampar. Pelatihan ini berguna bagi para guru dalam melakukan penilaian terhadap siswa pada aspek non kognitif. Aspek non kognitif tersebut berupa sikap, minat, motivasi, rasa ingin tahu, tingkat kepercayaan diri, dan lain sebagainya. Aspek non kognitif tersebut secara tidak langsung memiliki pengaruh yang cukup besar terhadap munculnya semangat siswa dalam mengikuti proses pembelajaran. Dari aspek tersebut guru bisa mengetahui apa saja kendala yang dihadapi oleh siswa dan upaya apa yang dilakukan untuk mengatasinya. Adapun dampak yang diperoleh guru dari kegiatan ini adalah meningkatnya pemahaman guru-guru mengenai penilaian melalui tenik non tes.
\end{abstract}

Kata kunci: Instrumen Penilaian, Teknik Non Tes

\begin{abstract}
This community service is in MAN 4 Kampar. The material provided is an instrument of development non-test techniques in MAN 4 Kampar. The training is useful for teachers in student evaluation on non-cognitive aspects. The aspect of non-cognitive were attitude, interest, motivation, curiosity, self confidence, and so on. The aspect non-cognitive is significant influence on student motivation in the learning process. From these aspects the teacher can find out what is the problem of students and what is the solution. The impact of community service is to improved teacher understanding about assessment of non-test techniques.
\end{abstract}

Keywords: Assessment Instruments, Non-Test Techniques

\section{PENDAHULUAN}

Prestasi akademik merupakan salah satu indikator keberhasilan proses pendidikan. Hasil belajar tersebut dapat berupa pengetahuan atau kognitif, sikap atau afektif, dan keterampilan atau psikomotor (Kumara, 1990). Ranah afektif adalah ranah yang berkaitan dengan sikap dan nilai. Kemampuan afektif merupakan bagian dari hasil belajar dan memiliki peran yang penting. Pembelajaran dalam ranah afektif diperlukan untuk memudahkan perkembangan nilai, etika, estetika, dan perasaan di lingkungan belajar siswa (Karen \& Bruce, 2010). Keberhasilan pembelajaran pada ranah kognitif dan psikomotorik sangat ditentukan oleh kondisi afektif siswa. Siswa yang memiliki minat belajar dan sikap positif terhadap pelajaran akan merasa senang mempelajari mata pelajaran, sehingga diharapkan akan mencapai hasil pembelajaran optimal (Basrowi, 2012).

Terhadap prestasi akademik siswa, terdapat sejumlah kendala yang terjadi seperti kurangnya rasa ingin tahu, semangat, motivasi, maupun kepercayaan diri pada siswa. Dalam hal ini, guru perlu memperhatikan dan mengambil tindakan untuk dapat memperbaiki situasi seperti saat ini. Langkah ini perlu diawali dengan cara mengkaji ulang mengenai apa yang membuat kegagalan dalam proses pembelajaran. Apakah karena terlalu menekankan aspek pengetahuan kognitif atau terlalu minim dalam segi afektif. Keseimbangan ini perlu dibangun oleh guru, orang tua dan 
masyarakat. Karena pendidikan yang terus-menerus menekankan pengetahuan pada aspek kognitif, terbukti tidak mampu menciptakan suasana yang diimpikan bangsa ini. Kelemahan tersebut bisa ditelusuri oleh guru apa penyebabnya melalui angket yang diberikan kepada siswa atau melalui penilaian secara non tes.

Berdasarkan wawancara yang dilakukan pada beberapa guru di MAN 4 Kampar, diperoleh informasi bahwa masih ada guru yang kurang memahami bagaimana cara melakukan penilaian mengenai aspek afektif . Terhadap permasalahan tersebut, maka guru dapat melakukan penilaian teknik non tes dalam menilai aspek afektif. Penilaian ini dapat berguna untuk mengetahui permasalahan yang dihadapi siswa serta dapat dijadikan sebagai sebuah penelitian. Karena penelitian merupakan bagian penting yang harus dilakukan guru untuk meningkatkan kualitas diri. Peningkatan kualitas guru akan berdampak pada peningkatan kualitas peserta didiknya. Guru juga perlu memiliki sikap terbuka untuk melakukan perbaikan, bahkan perlu melakukan suatu inovasi. Jika hasil belajar belum tercapai secara maksimal, maka guru perlu mencari penyebab hal tersebut, kemudian melakukan perbaikan, meninjau kembali materi pelajaran, merumuskan tujuan, metode atau hal-hal lain yang menyebabkan kegagalan pencapaian tujuan pelajaran tersebut.

\section{METODE}

Pengabdian kepada masyarakat ini dilakukan melalui pelatihan pengembangan instrumen penilaian teknik non tes bagi guru MAN 4 Kampar. Pelatihan ini bermanfaat bagi guru dalam melakukan penilaian terhadap aspek non tes. Mekanisme pelaksanaan kegiatan pengabdian kepada masyarakat secara umum dilaksanakan dengan melakukan perencanaan/persiapan, pelaksanaan, observasi dan evaluasi, serta refleksi. Guru-guru diberikan kesempatan untuk membuat instrumen penilaian non tes setelah pemateri memaparkan materi.

\section{HASIL DAN PEMBAHASAN}

Pelaksanaan kegiatan ini dilakukan pada hari Sabtu, tanggal 10 Januari 2020. Adapun prosedur yang dilakukan pada pengabdian masyarakat di MAN 4 Kampar adalah: (1) Pemberitahuan pada sekolah mitra yang akan dijadikan lokasi pengabdian dengan mengirimkan surat pemberitahuan kepada pihak sekolah. Setelah itu dilakukan koordinasi untuk membahas teknis pelaksanaan kegiatan; (2) Sosialisasi program pengabdian. sosialisasi dilakukan dengan melakukan koordinasi dan menyampaikan pemberitahuan secara tertulis kepada kelompok kerja guru MAN 4 Kampar; (3) Penyusunan program pelatihan berdasarkan hasil identifikasi, hasil analisis permasalahan yang ada, hasil analisis kebutuhan, dan hasil analisis potensi sekolah, selanjutnya disusun program pelatihan.

Selanjutnya dilaksanakan tindakan berupa implementasi program. Kegiatan-kegiatan yang dilakukan dalam implementasi program adalah sebagai berikut: Pelaksanaan pengabdian dimulai dengan penyampaian teori yang terkait dengan materi pengabdian kepada masyarakat. Materi disampaikan dalam dua sesi yang diselingi dengan waktu istirahat. Materi yang disampaikan adalah (1) Menjelaskan pengertian evaluasi non tes, macam-macam evaluasi non tes, urgensi dari evaluasi non tes, (2) Menjelaskan langkah-langkah penyusunan instrumen non tes, (3) Menjelaskan jenis instrumen non tes, (4) Menjelaskan tentang penentuan kualitas instrumen non tes yang dikembangkan, (5) Membuat draft instrumen non tes.

Pada sesi pembuatan draft instrumen non tes, para guru didampingi oleh pemateri. Guru secara mandiri mempersiapkan materi-materi yang akan dilaksanakan pada perancangan pembelajaran. Para peserta sangat antusias mengikuti kegiatan pengabdian. Melalui kegiatan ini peserta menjadi lebih memahami cara membuat penilaian non tes. Hal tersebut sangat membantu para guru dalam menilai dan memahami siswa serta dapat menemukan solusi terhadap permasalahan yang dialami oleh siswa.

\section{SIMPULAN}

Penilaian yang dilakukan guru kepada siswa tidak hanya dilakukan melalui tes saja, namun juga dapat dilakukan melalui non tes. Penilaian non tes dilakukan untuk mengetahui aspek non 
kognitif seperti motivasi, rasa percaya diri, rasa ingin tahu, dan sebagainya. Penilaian non tes adalah suatu alat penilaian yang biasanya digunakan untuk mendapatkan informasi tertentu tentang keadaan peserta didik dengan tidak menggunakan tes. Adapun penilaian non tes ini berguna untuk mengetahui kemajuan dan kesulitan belajar serta mendapatkan informasi mengenai keaadaan siswa dalam mengikuti proses pembelajaran.

\section{SARAN}

Beberapa saran yang dapat disampaikan dari kegiatan pengabdian masyarakat ini adalah sebagai berikut:

1. Perlu dipersiapkan bahan referensi untuk dapat membuat draft penilaian non tes.

2. Guru hendaknya melakukan penilaian non tes, untuk mengetahui apa saja hambatan yang dihadapi siswa dari aspek non kognitif.

\section{UCAPAN TERIMA KASIH}

Ucapan terimakasih penulis sampaikan kepada Kepala MAN 4 Kampar beserta seluruh guru dan staf yang bersedia meluangkan waktu dan tenaganya, hingga pelatihan pengembangan instrumen teknik non tes dapat terlaksana dengan baik.

\section{DAFTAR PUSTAKA}

Basrowi, S. (2018). Evaluasi Belajar Berbasis Kinerja. Bandung: Karya Putra Darwati.

Kumara, A. (1990). Hubungan antara motivasi berprestasi dan kecemasan dengan prestasi belajar para mahasiswa fakultas psikologi UGM Tahun ajaran 1989/1990. Laporan hasil penelitian.

Karen, N.A \& Bruce, D.F. (2010). Affective learning: A taxonomy for teaching social work values", Journal of Social Work Values and Ethics. Volume 7 Number 2. 